\title{
PRINSIP BENTUK GEOMETRI UNTUK KEMUDAHAN PEMBELAJARAN MATEMATIKA PENYANDANG DISABILITAS
}

\author{
Indah Rahayu Panglipur ${ }^{1 *}$, Eric Dwi Putra ${ }^{2}$ \\ 1,2 IKIP PGRI Jember \\ * Corresponding Author. Email: indahmath89@ikipjember.ac.id \\ Received: 06 Agustus 2019; Revised: 18 Agustus 2019 ; Accepted: 30 September 2019
}

\begin{abstract}
ABSTRAK
Pendidikan para penyandang cacat juga harus mendapatkan perhatian yang sama dengan yang lainnya. Demikian juga dari segi kemudahan dan kenyamanan dalam mendapatkan pendidikan. Baik terkait dengan kemudahan dalam hal kenyamanan dalam belajar di sekolah. Pemerintah dalam beberapa tahun terakhir telah memberikan perhatian besar kepada para penyandang cacat. Ada begitu banyak program yang berkaitan dengan peningkatan layanan publik untuk penyandang disabilitas. Terkait dengan bagaimana mengembangkan pembelajaran yang baik dan dukungan untuk penerapan kualitas belajar. Di beberapa sekolah inklusi di Jember, mereka sudah memiliki beberapa media yang mendukung proses pembelajaran. Terutama untuk mata pelajaran matematika yang mata pelajarannya masih cukup sulit. Lalu itu diperlukan untuk menyediakan media yang memfasilitasi proses pembelajaran dan memfasilitasi pemahaman. Itu Tujuan dari penelitian ini adalah untuk menemukan prinsip geometri yang dapat dengan mudah dan aman digunakan untuk pembelajaran matematika para penyandang cacat. Dalam penelitian ini subjek yang diamati dibatasi untuk orang dengan gangguan penglihatan. Jenis penelitian yang digunakan dalam penelitian ini adalah penelitian kualitatif dengan pendekatan deskriptif. Dari hasil pengamatan dan wawancara yang telah dilakukan diperoleh, dapat disimpulkan bahwa prinsip-prinsip geometri yang dapat dengan mudah dan aman digunakan belajar bagi para penyandang cacat adalah sudut tumpul, permukaan kasar, dan dibuat lebih menonjol.

Kata kunci: geometri, matematika, penyandang disabilitas

How to Cite: Panglipur, I, R., Putra, E, D. (2019). Prinsip Bentuk Geometri untuk Kemudahan Pembelajaran Matematika Penyandang Disabilitas. Histogram: Jurnal Pendidikan Matematika, 3(2), 182 - 188, doi: http://dx.doi.org/10.31100/histogram.v3i2.429 Permalink/DOI: http://dx.doi.org/10.31100/histogram.v3i2.429
\end{abstract}

\section{PENDAhULUAN}

Pendidikan merupakan hak seluruh warga Negara Indonesia. Sehingga seluruh masyarakat Indonesia tanpa terkecuali mempunya kesamaan hak mendapatkan pendidikan. Dalam mendapatkan pendidikan tentunya para penyandang disabilitas juga harus mendapatkan perhatianyang sama dengan lainnya. Begitu juga dalam hal kemudahan dan kenyamanan dalam mendapatkan pendidikan. Baik terkait dengan kemudahan dalam segi kenyamanan dalam belajar di sekolah. Pemerintah pada tahun belakangan ini telah This is open access article under the CC-BY-SA-license. 


\section{Histogram: Jurnal Pendidikan Matematika, 3 (2), 2019 - 183 Indah Rahayu Panglipur, Eric Dwi Putra}

memberikan perhatian yang cukup besar bagi khususnya penyandang disabilitas. Hal tersebut sejalan dengan kepala daerah kabupaten jember yaitu bupati Jember yang sangat memperhatikan terhadap para penyandang disabilitas. Banyak sekali program yang terkait peningkatan pelayanan public bagi penyandang disabilitas. Salah satu bidang yang tak boleh terlewat dari program tersebut adalah pada bidang pendidikan. Sekolah sebagai tempat untuk mendapakan ilmu harus turut ambil bagian dalam rangka

menyukseskan program pemerintah. Penyandang disabilitas yang mempunyai sekolah kusus/sekolah inklusi tentunya sangat membutuhkan perhatian kita bersama. Terkait bagaimana mengembangkan pembelajaran yang baik dan mendukung guna terlaksananya pembelajaran yang berkualitas. Pada beberapa sekolah inklusi yang ada di jember telah mempunyai beberapa media pendukung proses pembelajaran. Utamanya untuk mata pelajaran matematika yang masih menjadi mata pelajaran yang cukup sulit. Maka perlu diberikan suatu media yang memudahkan dalam proses pembelajaran dan memudahkan dalam pemahaman.

Peneliti tertarik untuk meneliti tentang prinsip bentuk geometri yang dapat memudahkan para penyandang disabilitas dalam belajar matematika. Tujuan dari diadakannya penelitian ini adalah untuk menemukan prinsip bentuk geometri yang dapat memudahkan dan aman digunakan untuk pembelajaran para penyandang disabilitas. Dalam penelitian ini subyek yang diamati dibatasi untuk penyandang disabilitas tuna netra. (Panglipur, 2015) Untuk mendapatkan prinsip geometri yang sesuai dengan asas kemudahan bagi tuna netra maka peneliti mengadakan penelitian pada sarana umum publik yang diakses bagi para penyandang disabilitas. Beberapa akses publik yang diteliti adalah jalur pemandu (Guilding block dan Warning block) dan Handrail.

Jalur pemandu, dan handrail berdasarkan (14/Prt/M/2017, 2017) Tentang Persyaratan Kemudahan Bangunan Gedung yaitu mengenai bentuk dan teksturnya. Sedangkan pegangan rambat (handrail) harus memenuhi standar ergonomis yang aman dan nyaman untuk digenggam serta bebas dari permukaan tajam dan kasar. Pada penyandang disabilitas yang digunakan dalam kehidupan sehari-hari harus mempunyai prinsip keamanan dan kemudahan.

Menurut Hartono (2009:1) mengemukakan bahwa Geometri berasal dari bahasa latin "geometri", geo yang berarti tanah sedangkan metria yang berarti ukuran. Di indonesia geometri diterjemahkan sebagai ilmu ukur. Geometri adalah cabang matematika yang mempelajari titik, garis, bidang dan benda-benda ruang beserta sifat, ukuran dan 


\section{Histogram: Jurnal Pendidikan Matematika, 3 (2), 2019 - 184 Indah Rahayu Panglipur, Eric Dwi Putra}

hubungannya dengan yang lain. Objek geometri adalah benda pikir yang berasal dari benda nyata yang diabstraksikan dan diidealisasikan.

Diabstraksikan yaitu tidak diperhatikan warna, bau, suhu dan sifat-sifat yang lain. Menurut Suydam (Husnain, 2016) mengatakan bahwa tujuan pembelajaran geometri adalah ,pengembangkan kemampuan berpikir logis, intuisi spasial tentang dunia nyata, penanaman pengetahuan yang dibutuhkan untuk matematika lanjut, mengajarkan cara membaca dan menginterpretasikan argumen matematika. Bitebrands menyatakan bahwa "Bentuk geometri adalah bentuk yang secara umum mempunyai kontur yang tegas dalam berbagai arah". Geometri terdiri dari beberapa bangun. (Saputri, 2016) membagi klasifikasi bentuk geometri diantaranya adalah geometri 2 dimensi atau sering disebut dengan bangun datar dan geometri 3 dimensi atau sering disebut dengan bangun ruang. Prinsip-prinsip geometri yang ada pada bangun datar berkaitan dengan rusuk penyusun dan sudut yang terbentuk.

Sedangkan menurut Lelly Nuraviva (2016, n.d.) bahwa penyandang disabilitas adalah orang yang mengalami keterbatasan fisik dan mental sehingga mengalami kesulitan dalam berinteraksi dengan lingkungannya dan mengalami kesulitan menerima pelayanan publik yang bersifat aksibel. Secara harfiah tunanetra berasal dari dua kata, yaitu: tuna (tuno : jawa) yang berarti rugi yang kemudian diidentikkan dengan rusak, hilang, terhambat, terganggu dan tidak memiliki. Sedangkan netra (netro : jawa) yang berarti mata. Kata tunanetra adalah satu kesatuan yang tidak terpisahkan yang berarti adanya kerugian yang disebabkan oleh kerusakan atau tergannggunya organ mata, baik anatomis atau fiologis.

Pada penyandang disabilitas utamanya tuna netra dalam beraktivitas utamanya dalam kegiatanpembelajaran di kelas membutuhkan media yang tepat dan serta aman dalam penggunaanya. Sehingga dalam penelitian ini diberikan hipotesis terdapat beberapa prinsip bentuk geometri yang mempunyai sudut tumpul dan sisi yang panjang lebih timbul dipermukaan untuk kemudahaan pembelajaran matematika penyandang tuna netra.

\section{METODE PENELITIAN}

\section{A. Jenis Penelitian}

Jenis penelitian yang digunakan pada penelitian ini merupakan penelitian kualitif dengan pedekatan yang digunakan diskriptif (Moleong,L, 2012). Untuk mencapai tujuan penelitian ini yaitu menemukan prinsip bentuk geometri yang dapat memudahkan dan aman digunakan untuk pembelajaran para penyandang disabilitas 


\section{Histogram: Jurnal Pendidikan Matematika, 3 (2), 2019 - 185 Indah Rahayu Panglipur, Eric Dwi Putra}

\section{B. Prosedur Penelitian}

Kegiatan penelitian yang dilakukan dengan mengadakan pertemuan khusus pada 2 subyek diluar jam pelajaran di kelas. Pertemuan dilakukan pada waktu yang berbeda pada setiap subyeknya. Pertemuan dilakukan sebanyak 3 kali. Kegiatan observasi dilakukan pada 2 pertemuan dan kegiatan wawancara dilakukan pada 1 pertemuan.

\section{Subyek Penelitian}

Subyek penelitian ini adalah 2 orang siswa SMP Inklusi jember. Sekolah ini merupakan sekolah rujukan terbaik di daerah Jember. Dengan pertimbangan tersedianya cukup media pembelajaran matematika yang mendukung.

\section{Instrumen Penelitian}

Sumber data yang digunakan berasal dari hasil observasi dan wawancara. Sedangkan instrument yang digunakan meliputi lembar observasi aktivitas, dan lembar wawancara. Uji keabsahan data menggunakan triangulasi sumber. Analisis penelitian ini adalah analisis deskriptif kualitatif, yaitu penelitian ini lebih bersifat mendeskripsikan data berdasarkan fakta dan keadaan yang terjadi di kelas tersebut. Sebelum melakukan penelitian intrumen yang digunakan diuji validitas terlebih dahulu oleh 2 validator ahli yang berkompeten yaitu dosen pendidikan matematika IKIP PGRI Jember yang mempunyai kompetensi dibidang penelitian kualitatif. Adapun langkah-langkah dalam penelitian ini adalah observasi awal, identifikasi masalah dan menentukan rumusan masalalah, penyusunan instrument penelitian, melakukan validasi, penelitian pada subyek yang telah ditentukan, uji keabsahan data, pengumpulan data hasil penelitian, pemisahan data primer dan skunder, analisis data, pembahasan, dan kesimpulan.

\section{HASIL DAN PEMBAHASAN}

\section{A. Hasil Penelitian}

Adapun hasil dari penelitian ini adalah hasil validasi instrument, hasil observasi , dan hasil wawancara. Hasil validasi instrument, Penelitian ini dibantu oleh 2 validator ahli dengan hasil validasi ditunjukan pada gambar 1 berikut. 
Histogram: Jurnal Pendidikan Matematika, 3 (2), 2019 - 186

Indah Rahayu Panglipur, Eric Dwi Putra

\begin{tabular}{clc}
\hline No. & Aspek & $\begin{array}{c}\text { Rata-rata Skor } \\
(\mathbf{V 1}, \mathbf{~ V 2})\end{array}$ \\
\hline 1. & Kejelasan bahasa & 3,8 \\
2. & Kesesuaian & 4 \\
3. & keterkaitan & 3,6 \\
\hline & Rata-rata & 3,8 \\
\hline
\end{tabular}

Gambar 1. Hasil Validasi Lembar Observasi

Berdasarkan gambar 1 dapat dilihat hasil rata-rata skor yang diberikan oleh validator 1 (V1) dan validator 2 (V2). Dalam tiga aspek tersebut sudah memenuhi kriteria instrument yang baik. Sehingga dapat diambil kesimpulan bahwa instrument tersebuta valid dan dapat digunakan tanpa ada revisi.

Hasil Observasi yang dilakukan pada penelitian ini pada 2 subyek yaitu S1 dan S2. Hasil observasi pada subyek disajikan dalam gambar 2 berikut.

\begin{tabular}{|c|c|c|c|}
\hline No. & Aspek & S1 & S2 \\
\hline \multicolumn{4}{|c|}{ 1. Guilding block } \\
\hline & $\begin{array}{l}\text { a. menunjukkan bentuk } \\
\text { geometri }\end{array}$ & 3 & 2 \\
\hline & $\begin{array}{l}\text { b. menunjukkan unsur-unsur } \\
\text { geometri }\end{array}$ & 2 & 2 \\
\hline & $\begin{array}{l}\text { c. mengenali fungsi tiap } \\
\text { bentuk geometri }\end{array}$ & 3 & 3 \\
\hline & $\begin{array}{l}\text { d. mengenali perkirann } \\
\text { ukuran unsur geometri }\end{array}$ & 2 & 2 \\
\hline \multicolumn{4}{|c|}{ 2. Warning block } \\
\hline & $\begin{array}{l}\text { a. menunjukkan bentuk } \\
\text { geometri }\end{array}$ & 3 & 3 \\
\hline & $\begin{array}{l}\text { b. menunjukkan unsur-unsur } \\
\text { geometri }\end{array}$ & 3 & 3 \\
\hline & c. mengenali fungsi tiap & 2 & 3 \\
\hline
\end{tabular}

Gambar 2. Hasil Observasi Subyek

Berdasarkan Gambar 2 memperlihatkan bahwa subyek 1 (S1) memperoleh ratarata 2,42 sedangkan subyek 2 (S2) nilai rata-ratanya adalah 2,59. Hasil wawancara dari kegiatan wawancara dilakukan setelah kegiatan pembelajaran selesai. Pada awalnya dilakukan kepada S1 selanjutnya ke S2. Hasil wawancara pada S1 adalah subyek dapat menyebutkan dan mengenali unsur pendukung bangun geometri melalui prinsip kondisi permukaan dan melalui bentuknya yang menonjol. Sedangkan untuk mengetahui menunjukan unsur geometri dengan benar yaitu sudut dan rusuk dapat dikenali karena sudutnya yang tumpul sehingga tidak melukai, meskipun sudutnya yang tumpul akan tetapi 


\section{Histogram: Jurnal Pendidikan Matematika, 3 (2), 2019 - 187 Indah Rahayu Panglipur, Eric Dwi Putra}

masih dapat membedakan sudut siku-siku dan yang bukan sikusiku. Bangun geometri yang dapat disebutkan adalah persegi panjang, lingkaran, dan tabung. Sedangkan hasil wawancara pada S2 menyatakan bahwa dapat menyebutkan dan mengenali karena bentuk permukaan yang lebih menonjol sehingg dapat mengetahui sudut dan rusuknya. Sedangkan sudut yang dikenali dengan menggunakan sudut yang tumpul karena tidak melukai jarinya. Namun subyek 2 ini juga bisa menyebutkan bahwa persegi panjang semua sudutnya adalah siku-siku. Sedangkan lingkaran yang dikenali karena tidak ada sisinya yang terputus, semuanya nyambung.

\section{B. Pembahasan}

Pembahasan dari hasil observasi dan wawancara pada penelitian ini bahwa pada S1 dan S2 dapat menyebutkan dan mengenali unsur pendukung geometri pada Guilding block, Warning block, dan handrail. Pada unsur geometri yang ada dapat disebutkan dengan baik meskipun pada S2 masih ada beberapa yang ragu namun dapat menyebutkan dengan tepat. Hal yang membantu subyek ternyata adalah dengan mengenali sudut dan permukaan dari pada Guilding block, Warning block, dan handrail. Hal ini menjadi sangat menarik karena dari penemuan tersebut dapat dijadikan dasar landansan tentang prinsip pembuatan media pembalajaran selanjutnya yang mudah dan aman untuk digunakan dalam pembelajaran.

\section{KESIMPULAN DAN SARAN}

Kesimpulan yang dapat diambil dari penelitian ini yaitu Prinsip Bentuk Geometri Untuk Kemudahan Pembelajaran Matematika Penyandang Disabilitas (tuna netra) melalui hasil observasi dan wawancara. Dari hasil observasi dan wawancara yang telah diperoleh maka dapat diambil kesimpulan bahwa prinsip bentuk geometri yang dapat memudahkan dan aman digunakan untuk pembelajaran para penyandang disabilitas adalah sudut yang tumpul, permukaan yang kasar, serta dibuat lebih menonjol. Saran yang dapat dilakukan adalah dalam media pembelajaran bagi penyandang disabilitas utamanya tuna netra harus memperhatikan prinsip-prinsip yang sudah ditemukan pada penelitian ini yaitu menggunakan sudut tumpul, permukaan yang kasar, serta mempunyai bagian-bagian yang menonjol untuk mudah dipahamai dan mudah digunakan sehari-hari. 
Histogram: Jurnal Pendidikan Matematika, 3 (2), 2019 - 188

Indah Rahayu Panglipur, Eric Dwi Putra

\section{DAFTAR PUSTAKA}

14/Prt/M/2017, P. M. P. U. D. P. R. N. (2017). Tentang Persyaratan Kemudahan Bangunan Gedung. jember: Dinas Perumahan Rakyat Kawasan Permukiman dan Cipta Karya. 2016, P. D. K. J. N. 7 T. (n.d.). Tentang Perlindungan Dan Hakhak Peyandang Disabilitas. Husnain. (2016). Membangun Konsep Segitiga Melalui Penerapan Teori Van Hiele. Jurnal Pendidikan, 21(1), 12-50.

Moleong,L, J. (2012). Metodologi Penelitian Kualitatif Edisi Revisi. Bandung: PT Remaja Rosdakarya.

Panglipur, I. R. (2015). Penerapan Metode Visual Finger Dalam Belajar Bangun Ruang Pada Anak Berkebutuhan Khusus ( Autis ). Seminar Nasional Matematika Dan Pendidikan Matematika UNY, 389-392.

Saputri, I. A. (2016). Upaya Peningktan Kemampuan Mengenal Bentuk Geometri Melalui Pembelajaran Berbasis Multimedia Pada Anak Kelompok B Di RA Muslimat NU Plosogede. yogyakarta. 